\title{
POTENSI PENINGKATAN EFISIENSI KAPAL MASA DEPAN: TINJAUAN ASPEK DESAIN DAN OPERASIONAL KAPAL
}

\author{
I Ketut Aria Pria Utama \\ Departemen Teknik Perkapalan \\ Institut Teknologi Sepuluh Nopember
}

\begin{abstract}
ABSTRAK
Fenomena kerusakan lingkungan seperti emisi gas rumah kaca, polusi, sibakan gelombang (wash) dan kebisingan cenderung meningkat. Masalah lingkungan ini ditinjau dari faktor ekonomi, seperti kenaikan biaya kebutuhan bahan bakar, merekomendasikan usaha untuk meminimalkan kebutuhan daya dorong kapal.

Berbagai metode dan perangkat untuk mengurangi daya dorong ditinjau dan dibahas. Metode yang paling menguntungkan, dari sudut pandang yang layak dan praktis, diidentifikasi dan diukur. Ditemukan bahwa potensi pengurangan pada hambatan bentuk lambung yang ada relatif kecil, namun pengoptimalan interaksi lambung, baling-baling dan kemudi menawarkan prospek perbaikan yang sangat menjanjikan. Potensi penghematan terbesar pada daya yang timbul adalah dari strategi optimasi strategi operasional seperti pemilihan desain trim, kecepatan dan rute berdasarkan cuaca.
\end{abstract}

Potensi konflik kepentingan saat mempertimbangkan persyaratan ekonomi dan lingkungan diselidiki dan didiskusikan. Metodologi dan prosedur perancangan yang sesuai, dengan mempertimbangkan faktor ekonomi dan lingkungan, disarankan untuk merancang kapal masa depan.

\section{PENDAHULUAN}

Perancangan kapal niaga selalu ditekankan pada kelayakan ekonomi. Nilai ekonomis tersebut terdiri dari biaya pembangunan, gaji kru, biaya operasional dan, khususnya, biaya bahan bakar yang berkaitan dengan kecepatan operasional yang dipilih. Hal ini perlu dikombinasikan sedemikian rupa sehingga pemilik kapal mendapatkan tingkat pengembalian investasi yang memadai dengan tingkat risiko tertentu. Organisasi Maritim Dunia (IMO) pada tahun 2012 [1], [2] menyoroti kebutuhan yang sangat penting untuk mengurangi emisi $\mathrm{CO}_{2}$, secara global sudah terhitung sekitar $3-4 \%$ emisi antropomorfik, dan proporsi ini akan meningkat jika emisi ini tidak dikendalikan, walaupun kekhawatiran ini bukan hal yang baru, [3]. Keprihatinan terhadap kerusakan lingkungan lainnya terkait dengan pengendalian polusi, kebisingan bawah air, anti-fouling, penggantian air balas dan wave-wash (sibakan gelombang yang tidak diinginkan). Tekanan ekonomi dan faktor lingkungan digabungkan untuk menciptakan kebutuhan akan penilaian baru terhadap perkiraan daya pendorong kapal dan pemilihan mesin yang sesuai, serta desain lambung kapal pada pembangunan kapal baru. Kedua persoalan tersebut menunjukkan kebutuhan untuk meminimalkan daya dorong kapal. Meminimalkan daya pendorong dapat diatasi pada tahap perancangan, dalam hal desain bentuk lambung, desain propulsor, dan selama operasi yang dapat mencakup penggunaan desain trim yang sesuai, pemilihan rute dan kecepatan yang lebih lambat.

Salah satu tantangan bagi operator kapal adalah dikaitkan dengan kesulitan dalam menilai manfaat sebenarnya dari teknologi retrofit (teknologi baru), sedangkan untuk membangun kapal baru, peningkatan investasi dalam desain kapal melalui teknik komputasi dan eksperimental dapat membantu mengoptimalkan bentuk lambung dibandingkan dengan bentuk yang lebih tradisional dengan biaya pembangunannya. Dengan demikian dapat diharapkan bahwa penggerak ekonomi dari biaya bahan bakar yang lebih tinggi akan menargetkan penggunaan bahan bakar yang lebih rendah dan dengan demikian akan mengurangi emisi. Umur kapal yang besar, biasanya 20-30 tahun, bekerja melawan pengurangan emisi secara cepat. Untuk retrofit, kemungkinan beberapa bentuk kontrol aliran tambahan dapat memperbaiki efisiensi pendorong [4]. Memang, kemampuan untuk merancang perangkat semacam itu sehingga, di seputar profil operasional khas kapal tertentu, penghematan bahan bakar bisa dijamin masih sangat banyak pertanyaan terbuka

Tujuan dari makalah ini adalah memberikan evaluasi sistematis mengenai cara mengurangi emisi $\mathrm{CO}_{2}$ dengan mengurangi daya dorong yang dibutuhkan dan mengembangkan metodologi perancangan yang akan mempertimbangkan masalah ekonomi dan lingkungan. 


\section{MENGUKUR DAMPAK LINGKUNGAN DARI PROPULSI KAPAL}

Emisi dari kapal terdiri dari NOx, SOx dan $\mathrm{CO}_{2}$. Emisi NOx dan SOx memiliki dampak yang relatif lokal dan produksi dan kontrolnya terutama bergantung pada jenis bahan bakar dan mesin. Di wilayah di mana banyak kapal beroperasi, seperti Selat Inggris dan North Sea, ini dapat menyebabkan konsentrasi dan peraturan yang relatif tinggi, melalui IMO, memperkenalkan persyaratan operasional spesifik untuk meminimalkan emisi ini, [5], [6]. Emisi $\mathrm{CO}_{2}$ memiliki dampak iklim global dan upaya terkonsentrasi di seluruh dunia untuk mengurangi hal ini. Untuk memantau dan mengukur emisi CO2, International Maritime Organization (IMO) telah mengembangkan Energy Efficiency Design Index (EEDI), IMO [1], [2].

Bentuk fundamental dari Index tersebut adalah:

$$
\text { EEDI }=\frac{\mathrm{CO}_{2} \text { emission }}{\text { Transport work }}
$$

Bentuk umum Indeks tersebut, seperti yang diusulkan oleh IMO, adalah sebagai berikut:

$$
\text { EEDI }=\frac{P \times s f c \times C_{F}}{C \times V} \quad \mathrm{gmCO}_{2} / \text { tonne.mile }
$$

Dimana $\mathrm{P}$ adalah power $(\mathrm{kW})$, sfc adalah konsumsi bahan bakar spesifik (gm / kW.hr), $\mathrm{C}_{\mathrm{F}}$ adalah konversi $\mathrm{CO}_{2}$ (tonne $\mathrm{CO}_{2} /$ tonne fuel), $\mathrm{C}$ adalah kapasitas kapal (deadweight ton atau Gross Tonnage) dan V kecepatan (mil laut / jam (knot), atau km / jam). Dengan demikian, EEDI dapat dilihat sebagai ukuran efisiensi $\mathrm{CO}_{2}$ dari sebuah kapal. Ini adalah persamaan umum, atau general, dari persamaan tersebut sebagai power terdiri dari daya pendorong dan mesin bantu, kapasitas (C) kapal pada bobot utamanya adalah bobot mati; kapal penumpang akan menggunakan tonase kotor. Kecepatan harus didefinisikan dengan jelas karena bisa dianggap sebagai kecepatan desain, atau beberapa kecepatan rata-rata yang diharapkan dalam operasi. Begitu pula dengan desain daya pendorong ketika air tenang, atau daya yang memperhitungkan kenaikan rata-rata akibat cuaca.

Ketika mempertimbangkan keseluruhan bentuk EEDI, jelas bahwa untuk mengurangi indeks tersebut sebuah proposal desain kapal pada kecepatan tertentu, penurunan daya pendorong harus dicapai dan / atau perbaikan yang dilakukan dalam efisiensi mesin dengan pengurangan sfc. Meningkatkan efisiensi dasar desain kapal dengan memaksimalkan kapasitas bobot mati (C) untuk displacement tertentu, maka daya (P), juga harus dieksplorasi.

Untuk tujuan penjelasan dan komparatif, makalah ini menggunakan indeks bentuk umum, Persamaan (2), dengan $\mathrm{P}$ sebagai daya pendorong, kapasitas $\mathrm{C}$ sebagai bobot mati dalam ton dan $\mathrm{V}$ kecepatan operasidalamknot. Contoh kapal kargo / kapal kontainer yang ditunjukkan pada Tabel 1 dengan asumsi $\mathrm{sfc}=190 \mathrm{gm} / \mathrm{kW} \cdot \mathrm{hr}$ dan $\mathrm{CF}=3,17$ ton $\mathrm{CO} 2$ / tonne fuel (IMO [1]) akan memiliki EEDI $=12,89 \mathrm{gm} /$ tonne.mile.

Table 1:Partikular contoh kapal kargo / kapal kontainer

\begin{tabular}{ll}
\hline$L$ & $145.0 \mathrm{~m}$ \\
\hline$B$ & $24.0 \mathrm{~m}$ \\
\hline$T$ & $10.7 \mathrm{~m}$ \\
\hline$C_{\mathrm{B}}$ & 0.710 \\
\hline$\Delta$ & 27100 tonnes \\
\hline Deadweight & 20500 tonnes \\
\hline$V$ service & 16 knots \\
\hline$P$ sservice power & $6680 \mathrm{~kW}$ \\
\hline
\end{tabular}

Sebuah bentuk kontrol emisi $\mathrm{CO}_{2}$ telah diperkenalkan dan batas telah ditetapkan pada EEDI untuk membangun kapal baru, untuk beberapa jenis kapal, yang mulai berlaku pada tahun 2012. Hal ini segera sangat menentukan definisi spesifik masingmasing komponen dalam Persamaan (2), Referensi [1], bersama dengan prosedur dan keputusan perancangan kapal masa depan. Perlu dicatat bahwa karena daya (P) terkait dengan daya terpasang, mungkin ada dorongan untuk mengurangi margin yang diasumsikan, dengan adanya potensi masalah keamanan seperti ketidakmampuan untuk bertahan di laut yang ekstrim.

\section{POWERING}

\subsection{KONSEP KESELURUHAN}

Tujuan keseluruhan dari sistem powering adalah mengubah energi bahan bakar menjadi thrust yang berguna (T) agar sesuai dengan hambatan kapal (R) pada kecepatan yang dibutuhkan (V), Gambar 1 .

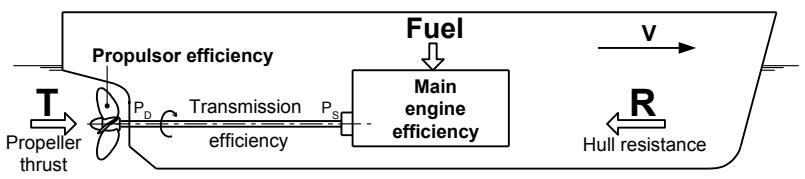

Gambar 1: Keseluruhan konsep konversi energi pada sistem penggerak kapal

Efisiensi keseluruhan sistem propulsi akan bergantung pada:

- jenis bahan bakar, sifat dan kualitas;

- efisiensi mesin dalam mengubah energi bahan bakar menjadi tranmisi daya yang berguna; dan

- efisiensi propulsor dalam mengubah daya (biasanya rotasi) menjadi thrust $(\mathrm{T})$.

Studi ini mengkonsentrasikan pada kinerja lambung dan propulsor, terutama mengingat, untuk 
sejumlah kendala, bagaimana ketahanan (R) dapat dikurangi dan dorongan $(\mathrm{T})$ dapat meningkat.

Untuk sebuah kapal dengan displacement tertentu bergerak dengan kecepatan konstan di laut yang tenang, tidak akan ada gaya netto yang bekerja pada lambung kapal, baling-baling dan bangunan atas saat tekanan permukaan dan tegangan geser diintegrasikan ke semua permukaan ini. Energi hanya dipasok untuk menopang propulsi melalui poros baling-baling. Kehadiran perangkat yang dirancang untuk meningkatkan efisiensi keseluruhan hanya dapat dinilai saat beroperasi di hadapan semua komponen lainnya.

Tipe bahan bakar dan mesin yang tersedia dirangkum kemudian. Rincian daftar mesin propulsi dapat ditemukan pada beberapa sumber seperti Woodyard [7] dan Molland [8].

\subsection{KOMPONEN POWERING}

Komponen utama powering dapat diidentifikasi sebagai berikut:

\section{2(a) Propulsif power}

Daya yang dikirimkan ke baling-baling, delivered power (PD), dapat didefinisikan sebagai:

$$
\begin{aligned}
& \text { Delivered power }\left(P_{D}\right)=\frac{\text { Effective power }\left(P_{E}\right)}{\text { Quasi propulsive coefficient }\left(\eta_{D}\right)} \\
& \text { Effective power }\left(P_{E}\right)=R \cdot V
\end{aligned}
$$

dimana $\mathrm{R}$ adalah hambatan total $(\mathrm{kN})$ dari lambung dan tonjolan, bersama dengan hambatan udara di atas lambung dan bangunan atas. $\mathrm{V}$ adalah kecepatan kapal (m/s).

Hambatan total lambung terdiri dari gesekan, tekanan kental (atau bentuk) dan komponen gelombang. Komponen ketahanan lambung dasar ini berlaku untuk kapal displacement dan sebagian besar kapal semi-displacement. Komponen lebih lanjut adalah drag pada tonjolan dan drag pada udara, keduanya dibahas kemudian. Untuk kapal yang lebih cepat, komponen resistensi lainnya timbul seperti transom, spray dan induced drag.

3.2(b) Tingkat relatif komponen powering untuk berbagai jenis kapal

Pemecahan komponen hambatan lambung, sebagai proporsi total, telah dibuat untuk perwakilan jenis kapal, yaitu kapal tanker, kapal curah, kapal kontainer dan kapal penumpang dan feri catamaran berkecepatan tinggi. Ini diringkas dalam Tabel 2 . Rincian ini mengidentifikasi target yang mungkin terjadi untuk penghematan dalam hambatan lambung. Sangat menarik untuk dicatat dari Tabel 2 bagaimana bentuk lambung kapal tanker yang lebih lambat dan kapal pengangkut curah memiliki proporsi drag kental (friksi plus bentuk) yang tinggi, sedangkan untuk kapal kontainer dengan kecepatan lebih tinggi dengan lambung yang lebih ramping, resistansi gelombang memainkan bagian yang lebih penting. Untuk feri cepat, komponen yang paling signifikan adalah hambatan gelombang, dan banyak penelitian telah dilakukan dengan melakukan pengurangan komponen ini, misalnya dengan meningkatkan rasio length displacement atau mengubah jarak lambung catamaran untuk mengurangi interferensi gelombang, Molland dkk [9], [10].

\subsection{PENGURANGAN DALAM PROPULSIF POWER}

Fokus utama dengan potensi untuk mengurangi daya secara layak dan praktis dirangkum dalam Tabel 3. Ada banyak yang optimisyang dapat diklaim pada tingkat pengurangan untuk berbagai topik dan metode ini.

Bagian berikut menganalisis dan mendiskusikan kemungkinan pengurangan daya yang mungkin dicapai selama tahap perancangan dan selama operasi, mengingat perbaikan satu komponen dapat mengurangi kinerja yang lain.

Table 2: Perkiraan distribusi komponen hambatan. Hambatan udara ditunjukkan sebagai persentase dari total

\begin{tabular}{|c|c|c|c|c|c|c|c|c|c|c|}
\hline \multirow[b]{2}{*}{ Type } & \multirow[b]{2}{*}{$\begin{array}{r}\text { Lbp } \\
(\mathrm{m})\end{array}$} & \multirow[b]{2}{*}{$C_{\mathrm{B}}$} & \multirow[b]{2}{*}{$\begin{array}{l}\text { Dw } \\
\text { (tonnes) }\end{array}$} & \multirow{2}{*}{$\begin{array}{l}\text { Service } \\
\text { speed } \\
\text { (Knots) }\end{array}$} & \multirow{2}{*}{$\begin{array}{l}\text { Service } \\
\text { power } \\
(\mathrm{kW})\end{array}$} & \multirow[b]{2}{*}{$\mathrm{Fr}$} & \multicolumn{2}{|c|}{ Hull resistance } & \multirow{2}{*}{$\begin{array}{c}\text { component } \\
\text { Wave } \\
\% \\
\end{array}$} & \multirow{2}{*}{$\begin{array}{l}\text { Air } \\
\text { Drag } \\
\% \text { total } \\
\end{array}$} \\
\hline & & & & & & & $\begin{array}{l}\text { Friction } \\
\%\end{array}$ & $\begin{array}{c}\text { Form } \\
\%\end{array}$ & & \\
\hline Tanker & 330 & 0.84 & 250000 & 15 & 24000 & 0.136 & 66 & 26 & 8 & 2.0 \\
\hline Tanker & 174 & 0.80 & 41000 & 14.5 & 7300 & 0.181 & 65 & 25 & 10 & 3.0 \\
\hline Bulk carrier & 290 & 0.83 & 170000 & 15 & 15800 & 0.145 & 66 & 24 & 10 & 2.5 \\
\hline Bulk carrier & 180 & 0.80 & 45000 & 14 & 7200 & 0.171 & 65 & 25 & 10 & 3.0 \\
\hline Container & 334 & 0.64 & $\begin{array}{l}100000 \\
10000 \mathrm{TEU}\end{array}$ & 26 & 62000 & 0.234 & 63 & 12 & 25 & 4.5 \\
\hline Container & 232 & 0.65 & $\begin{array}{l}37000 \\
3500 \mathrm{TEU}\end{array}$ & 23.5 & 29000 & 0.250 & 60 & 10 & 30 & 4.0 \\
\hline $\begin{array}{l}\text { Catamaran } \\
\text { ferry }\end{array}$ & 80 & 0.47 & $\begin{array}{l}650 \text { pass } \\
150 \text { cars }\end{array}$ & 36 & 23500 & 0.700 & 30 & 10 & 60 & 4.0 \\
\hline
\end{tabular}
hambatan, yaitu total lambung ditambah total tonjolan ditambah udara. 
Table 3 Fokus utama untuk potensi pengurangan daya

\begin{tabular}{|c|c|}
\hline MENGURANGI HAMBATAN KAPAL & $\begin{array}{l}\text { Hull: bentuk, permukaan yang halus } \\
\text { Tonjolan: desain dengan hambatan rendah } \\
\text { Superstruktur (hambatan udara): desain dengan hambatan rendah }\end{array}$ \\
\hline MENINGKATKAN EFISIENSI PROPULSOR & $\begin{array}{l}\text { Pemilihan parameter desain yang tepat, permukaan propeller yang halus } \\
\text { Adaptasi pada aliran wake }\end{array}$ \\
\hline $\begin{array}{l}\text { OPTIMALISASI INTERAKSI LAMBUNG } / \\
\text { PROPELLER / RUDDER }\end{array}$ & $\begin{array}{l}\text { Optimasi distribusi wake } \\
\text { Minimalisasi thrust deduction } \\
\text { Pengkondisian Upstream flow } \\
\text { Pemulihan energi rotasi }\end{array}$ \\
\hline OPTIMALISASI STRATEGI UNTUK OPERASI & $\begin{array}{l}\text { Kecepatan, termasuk bergerak lambat } \\
\text { Trim: monitor / optimalkan } \\
\text { Rute cuaca } \\
\text { Pembersihan Hull / baling-baling }\end{array}$ \\
\hline
\end{tabular}

\section{PENGHEMATAN DAYA PADA TAHAP DESAIN}

\subsection{BENTUK LAMBUNG}

Hambatan lambung didominasi oleh parameter utama seperti $L / \nabla^{1 / 3}, C_{\mathrm{B}}, B / T$ dan $L C B$. Detail lokal, seperti penggunaan bagian ' $\mathrm{V}$ ' atau 'U' pada haluan dan / atau buritan, akan berpengaruh, seperti juga penggunaan bulbous bows. Tinjauan teknik yang digunakan untuk meminimalkan hambatan lambung, termasuk penggunaan eksperimen dan $C F D$, diberikan pada [11]. Investigasi bentuk buritan dijelaskan pada [12]. Penggunaan bulbous bows harus dilakukan dengan hati-hati karena ada area yang relatif spesifik dimana bisa digunakan untuk keuntungan. Area yang sesuai untuk penerapan bulbous bows dapat ditemukan di [13] dan dari hasil karya Kracht [14]. Ditemukan bahwa pilihan, dan biaya, penggunaan bulbous bows adalah desain yang spesifik. Hochkirch dan Bertram [15], misalnya, melaporkan penyelidikan spesifik, menggunakan CFD, ke dalam desain dan desain ulang bulbous bows untuk kapal kontainer saat mengepul.Generator vortex dapat digunakan untuk menyelaraskan kembali aliran ujung belakang dan pemisahan penundaan. Hal ini sering dilakukan untuk memberikan aliran bersih ke baling-baling, ketimbang harus mengurangi resistansi, Anon [16].

Penghematan dengan 'mengoptimalkan' bentuk lambung bergantung pada lambung datum atau titik awal. Jika lambung datum didasarkan pada praktik baik yang ada, dengan menggunakan informasi yang dipublikasikan untuk pengaruh pada hambatan parameter lambung utama dan bentuk lambung lokal, maka indikasinya adalah bahwa studi pengoptimalan lebih lanjut dapat memperoleh penghematan keseluruhan hingga sekitar 5\%.

\subsection{PERMUKAAN LAMBUNG YANG HALUS}

Terlihat dari Tabel 2 bahwa resistansi gesekan adalah $60 \%-70 \%$ dari total ketahanan lambung untuk kapal tanker, kapal curah dan kapal kontainer dan

Fakultas Teknik Universitas Pattimura,

ISSN : 2620-3995

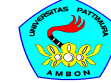

pengurangan komponen ini dapat memiliki manfaat yang signifikan.Permukaan lambung yang halus sangat penting untuk tingkat ketahanan gesekan kulit lambung.Permukaan yang halus, dengan kekasaran yang rendah, biasanya akan menyebabkan ketahanan tekanan gesek dan gesekan yang lebih rendah. Dari sudut pandang hidrodinamik, tujuan dasarnya adalah untuk memberikan permukaan lambung halus saat kapal dibangun dan untuk menjaga permukaan bersih halus dalam operasinya.Hal ini dapat dicapai dengan menggunakan lapisan cat yang canggih. Sebagai contoh, penelitian oleh Candries and Atlar [17] menunjukkan bahwa pengurangan resistansi gesekan kulit dari urutan 2\% sampai 3\% dapat dicapai dengan lapisan anti fouling.Banyak penelitian telah dilakukan untuk menunjukkan manfaat dari permukaan lambung yang halus, misalnya Townsin et al. [18], [19], [20]. Peningkatan resistensi yang signifikan akibat kekasaran dan fouling bisa terjadi dalam operasi kapal.Frekuensi docking untuk membersihkan lambung biasanya telah dinilai berdasarkan alasan ekonomi. Jika skema perdagangan emisi, atau beberapa bentuk subsidi karbon 'diperkenalkan, maka penekanannya mungkin akan berubah menjadi pengurangan kekuatan, yang didorong oleh pengurangan emisi $\mathrm{CO}_{2}$, dan bukan semata-mata untuk tujuan ekonomi.

\subsection{TONJOLAN}

Tonjolan, seperti lunas bilga, shaft brackets dan kemudi memerlukan desain yang hati-hati. Hal ini mungkin memerlukan tes visualisasi aliran atau penyelidikan CFD untuk mengoptimalkan penyelarasan lunas bilga danshaft brackets. Kemudi harus dianggap sebagai bagian dari kombinasi balingbaling dalam kaitannya dengan thrust deduction dan perubahan efisiensi propulsif, Molland and Turnock [21], Anon [16].Total hambatan pada tonjolan biasanya mencapai sekitar 5\% dari total hambatan untuk kapal berpenggerak tunggal dan $8 \%-15 \%$ untuk kapal berpenggerak ganda. Oleh karena itu, ada potensi menggunakan perancangan hati-hati untuk mendapatkan sebuah penghematan. Tantangan 
khusus adalah menilai pelemahan tambahan pada skala model ketika tonjolan sering kali berada dalam rezim aliran yang berbeda dengan skala penuh, [22].

\subsection{HAMBATAN UDARA}

Hambatan udara dari lambung dan supertruktur di atas umumnya merupakan proporsi yang relatif kecil dari total ketahanan kapal tanker dan kapal curah meskipun dapat menjadi signifikan untuk kapal kontainer dan feri cepat. Namun, untuk sebuah kapal besar, secara absolut, setiap pengurangan hambatan udara mungkin layak dilakukan. Perlu juga dicatat bahwa hambatan udara akan meningkat secara signifikan pada arahdatangnya angin.Nilai hambatan udara untuk kapal komersial biasanya dapat ditemukan di Isherwood [23], van Berlekom [24], Gould [25] dan Molland dan Barbeau [26]. Perbaikan pada hambatan superstruktur kapal komersial dengan superstruktur berbentuk kotak dapat dilakukan dengan membulatkan sudut, hal ini dapat mengurangi drag. Ditemukan bahwa pembulatan sudut tajam bisa bermanfaat, terutama untuk benda berbentuk kotak, Hoerner [27] dan Hucho [28]. Namun, pembulatan minimal $\mathrm{r} / \mathrm{BS}=0,05$ (di mana $\mathrm{r}$ adalah jari pembulatan dan BS adalah luasnya suprastruktur) diperlukan sebelum ada dampak signifikan pada hambatan. Pada dan di atas pembulatan ini, penurunan hambatan udara sebesar 15\% - 20\% dapat dicapai untuk bentuk kotak segi empat, walaupun tidak mungkin penurunan tersebut dapat dicapai dengan bentuk yang sudah cukup efisien. Perlu dicatat bahwa prosedur ini akan bertentangan dengan desain untuk produksi, dan penggunaan modul suprastruktur 'tipe kotak'.

Investigasi oleh Molland dan Barbeau pada hambatan superstruktur dari feri cepat yang besar mengindikasikan pengurangan koefisien drag udara (berdasarkan area frontal) dari sekitar 0,8 untuk titik akhir yang relatif kencang hingga turun 0,5 untuk ujung depan yang baik, hamabtan udara turun sekitar $38 \%$. Jika perubahan ini diterapkan pada feri pada Tabel 2, ini akan menyebabkan penurunan power keseluruhan sekitar 1,5\%.

\subsection{EFISIENSI PROPULSOR}

4.5(a) Efisiensi propulsio

Komponen koefisien koordinat kuasi $\left(\eta_{\mathrm{D}}\right)$ dapat ditulis:

$$
\eta_{\mathrm{D}}=\eta_{0} \cdot \eta_{\mathrm{H}} \cdot \eta_{R}
$$

Dimana $\eta_{0}$ adalah efisiensi open water dari balingbaling, $\eta_{\mathrm{H}}$ adalah efisiensi lambung dan $\eta_{\mathrm{R}}$ adalah efisiensi rotasi relatif.

$\eta_{R}$ memperhitungkan perbedaan antara baling-baling dalam kondisi open water dan ketika berada di belakang lambung kapal, dan biasanya terletak antara 0,98 sampai 1,02 .

$\eta_{H}$ memperhitungkan interaksi antara lambung dan baling-baling dan didefinisikan sebagai:

$$
\eta_{H}=\frac{(1-t)}{\left(1-w_{\mathrm{T}}\right)}
$$

dimana $\mathrm{t}$ adalah faktor thrust deduction dan wake fraction. $\eta_{\mathrm{H}}$ terletak biasanya antara 1,0 dan 1,25 untuk kapal displacement. Rumus tersebut menunjukkan bagaimana perubahan thrust deduction (t) karena, misalnya, dengan adanya kemudi atau perangkat lain akan mempengaruhi efisiensi balingbaling secara keseluruhan. Demikian pula, pengaruh wake fraction $\left(w_{\mathrm{T}}\right)$ dapat dilihat dan diukur.

$\eta_{0}$ adalah efisiensi baling-baling pada open water dan akan bergantung pada parameter baling-baling dan kondisi operasi.

4.5(b) Komponen individual efisiensi baling-baling pada open water:

Untuk seperangkat parameter baling-baling, $\eta_{0}$ dapat dianggap terdiri dari:

$$
\eta_{0}=\eta_{a} \cdot \eta_{r} \cdot \eta_{f}
$$

dimana $\eta_{a}$ adalah efisiensi ideal (atau aksial), $\eta_{r}$ menyumbang kerugian karena rotasi fluida yang disebabkan oleh baling-baling dan $\eta_{f}$ menyebabkan kerugian akibat gesekan daun, Dyne [29], [30], Molland dkk [ 31].

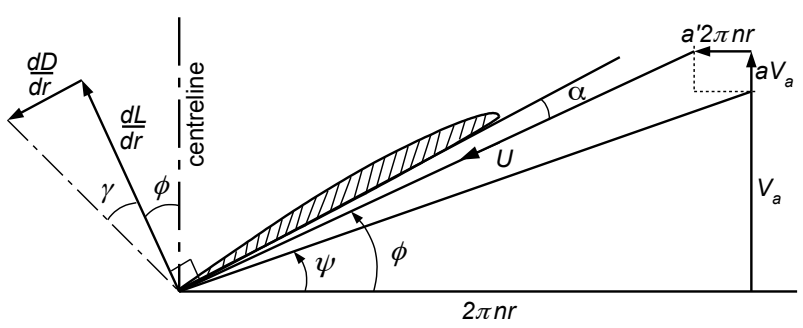

Gambar 3:Diagram elemen daun baling-baling

Investigasi telah dilakukan untuk menentukan nilai kemungkinan ketiga komponen efisiensi ini. Teori momentum elemen daun tersebut digunakan, [31], [32] dan, berdasarkan diagram elemen daun tersebut, Gambar 3, dapat ditunjukkan bahwa:

$$
\begin{aligned}
\eta_{a} & =\frac{1}{(1+a)} \\
\eta_{r} & =\left(1-a^{\prime}\right) \\
\eta_{f} & =\frac{\tan \phi}{\tan (\phi+\gamma)}
\end{aligned}
$$

dimana $a$ dan $a^{\prime}$ adalah faktor inflow aksial dan rotasi, yang berasal dari pertimbangan momentum 
dan koreksi jumlah baling-baling yang terbatas dengan menggunakan faktor koreksi Goldstein [31]. Investigasi menggunakan baling-baling dengan rasio pitch $P / D=1,0, B A R=0,700$ dan 4 daun untuk rentang nilai $\mathrm{J}$, sehingga thrust loading, CT, seperti ditunjukkan pada Tabel 4.

Table 4:Rentang investigasi thrust loadings

\begin{tabular}{l|c}
\hline$J$ & $C_{\mathrm{T}}$ \\
\hline 0.25 & 23.04 \\
0.35 & 10.32 \\
0.45 & 5.34 \\
0.55 & 2.94 \\
0.65 & 1.64 \\
0.75 & 0.86 \\
0.85 & 0.38 \\
0.90 & 0.20 \\
\hline
\end{tabular}

Koefisien thrust loading CT didefinisikan, dan terkait dengan $K_{\mathrm{T}} / J^{2}$, sebagai berikut:

$$
C_{T}=\frac{T}{0.5 \rho \frac{\pi D^{2}}{4} V a^{2}}=\frac{K_{T}}{J^{2}} \cdot \frac{8}{\pi}
$$

Untuk pitch yang tetap, penurunan $\mathrm{J}$ menyebabkan kenaikan thrust loading $K_{\mathrm{T}} / J^{2}$ atau $C_{\mathrm{T}}$.

Hasil penelitian ditunjukkan pada Gambar 4. Dapat dicatat bahwa kurva $\eta_{0}$ erat dengan tingkat tersebut untuk baling-baling Wageningen B4.70.

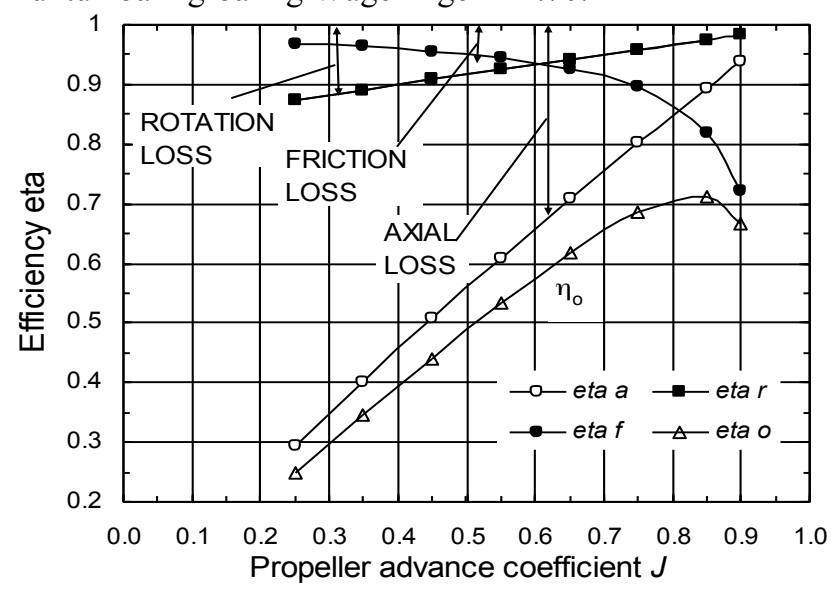

Gambar 4: Komponen efisiensi baling-baling

Bekerja dari $\mathrm{J}$ rendah ( $C_{\mathrm{T}}$ thrust loading tinggi) ke $\mathrm{j}$ yang lebih tinggi (thrust loading yang lebih rendah), terlihat bahwa kerugian rotasi menurun, kerugian friksional meningkat dan ada penurunan signifikan pada kerugian aksial. Pada kondisi desain tipikal katakan $\mathrm{J}=0,75\left(\mathrm{C}_{\mathrm{T}}=0,86\right)$ terlihat bahwa kerugian biasanya $60 \%$ aksial, $10 \%$ rotasi dan $30 \%$ gesekan. Pada $\mathrm{J}$ rendah, thrust loading yang lebih tinggi, dari J $=0,35\left(\mathrm{C}_{\mathrm{T}}=10,32\right)$ kerugian biasanya $80 \%$ aksial, $15 \%$ rotasi dan $5 \%$ gesekan.

Fakultas Teknik Universitas Pattimura,

ISSN : 2620-3995

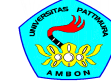

Perincian komponen individual $\eta_{0}$, Persamaan (7) dan Gambar 4 ini penting karena menunjukkan di mana penghematan potensial dapat dilakukan untuk memaksimalkan pemulihan energi yang hilang. Komentar berikut dibuat dengan beberapa metode praktis yang digunakan untuk meningkatkan efisiensi setiap komponen:

(i) $\eta_{\mathrm{f}}$ Penghematan dalam gesekan dapat dicapai dengan menggunakan ketebalan pisau yang minimum yang sesuai dengan pertimbangan kekuatan dan luasan daun minimum yang sesuai dengan persyaratan kavitasi. Pengurangan gesekan juga dapat dicapai dengan menurunkan kecepatan arus masuk lokal (dengan mengurangi putaran) dengan meningkatkan diameter yang sesuai. Kehilangan gesekan juga dapat dikurangi dengan mengurangi putaran dan meningkatkan pitch, meskipun hal ini akan menyebabkan kerugian rotasi meningkat yang mungkin harus dikompensasi oleh stators pada downstream. Permukaan yang halus mempengaruhi gesekan, terutama selama operasi. Indikasi penghematan potensial diperoleh dengan menggunakan teori momentum baling-baling dengan $J=0.75, P / D=1.0$ dan $B A R=0.700$. Ditemukan bahwa perubahan ketebalan daun $10 \%$ menyebabkan perubahan sekitar $1 \%$ - $2 \%$ pada $\eta_{0}$, penurunan BAR dari 0,700 menjadi 0,600 menyebabkan peningkatan $\eta_{0}$ sekitar $2 \%$ dan peningkatan koefisien drag dari $20 \%$ karena mengatakan kekasaran dan fouling menyebabkan penurunan $\eta_{0}$ dari $2 \%$ - 4\%.

(ii) $\eta_{\mathrm{r}}$ Pemulihan kehilangan rotasi dapat dicapai dengan berbagai cara. Cara yang paling efektif adalah menggunakan baling-baling kontra-rotasi, di mana sebagian besar kehilangan rotasi aliran dapat dilepaskan. Dengan tidak adanya baling-baling seperti itu, cara yang paling umum adalah dengan menggunakan pre- and post-swirl stators. Rudder (downstream of a propeller) bertindak sebagai stator post-swirl, tapi juga menghalangi aliran, mengakibatkan kerugian tekanan (aksial) yang dapat meniadakan sebagian besar penghematan rotasi. Preswirl (upstream) stators dapat memerlukan sirip, sementara post swirl downstream dapat memerlukan sirip yang menempel pada kemudi. Buritan asimetris dapat digunakan yang menempatkan pra-rotasi ke arus masuk baling-baling. Tingkat penghematan daya untuk berbagai perangkat ini dibahas di Bagian 4.6. Perlu dicatat bahwa sirip pre dan post swirl dan buritan asimetris dapat meningkatkan ketahanan, sehingga mengurangi beberapa penghematan efektif dalam efisiensi baling-baling.

(iii) $\eta_{\mathrm{a}}$ Kerugian aksial adalah yang terbesar, Gambar 4. Teori dan praktik menunjukkan bahwa peningkatan diameter dengan perubahan sepadan pada $P / D$ dan rpm akan menghasilkan perbaikan efisiensi aksial (bersamaan dengan beberapa perbaikan dalam efisiensi gesekan). Memaksimalkan 
diameter karenanya sangat penting. Mempercepat ducts dapat digunakan untuk keuntungan dalam kondisi thrust loading tinggi, meskipun gesekan aliran akan cenderung menghilangkan penghematan pada thrust loadings sedang atau rendah. Suatu upstream semi-duct telah digunakan untuk memperbaiki efisiensi aksial dengan mengarahkan bagian dari frictional wake ke dalam diameter balingbaling.

\section{5(c) Pengaruh diameter baling-baling}

Untuk mengukur pengaruh diameter baling-baling pada efisiensi pendorong, sebuah studi praktis dilakukan pada kapal kargo / kontainer kecil yang khusus diberikan pada Tabel 1. Survei terhadap kapal kontainer menunjukkan bahwa pilihan diameter baling-baling adalah antara $65 \%$ dan $74 \%$ terhadap draf beban desain. Nilai yang lebih rendah kemungkinan diterapkan dimana operasi diharapkan pada draft secara signifikan kurang dari pada desainload cases. Hal ini bisa menciptakan penalti daya yang signifikan. Misalnya, ketika rentang diameter ini diterapkan pada kapal $145 \mathrm{~m}$ pada Tabel 1, maka diameter baling-balingnya adalah antara $6.9 \mathrm{~m}$ dan $7.9 \mathrm{~m}$. Jika ini diubah menjadi perbaikan efisiensi baling-baling, maka urutan kenaikan ditunjukkan pada Gambar 5, yang mencakup perubahan $w_{\mathrm{T}}$ dan $\mathrm{t}$ (karenanya $\eta_{\mathrm{H}}$ ) dengan perubahan diameter. Dengan efisiensi baling-baling $\eta_{\mathrm{D}}$, Persamaan (5), meningkat dari 0,726 menjadi 0,765 , terjadi peningkatan sekitar 5\%. Untuk dapat menggabungkan peningkatan diameter yang sedemikian besar tidak mungkin terjadi dalam situasi perancangan tertentu, namun daya tarik untuk menerapkan setiap kenaikan diameter tampak jelas.

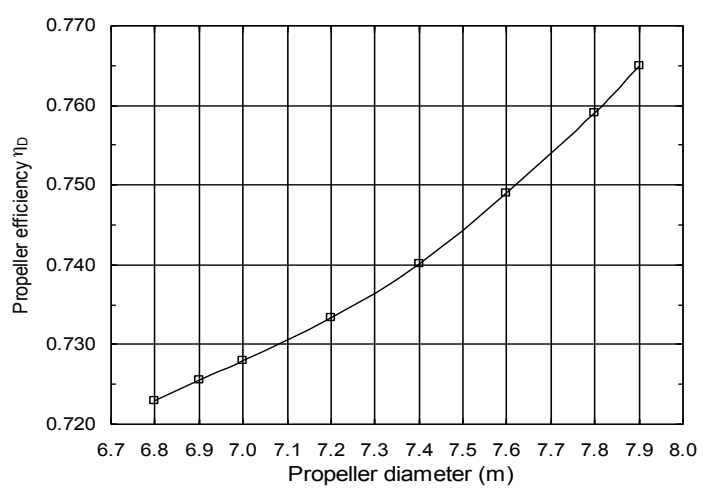

Gambar 5: Perubahan efisiensi baling-baling $\eta_{\mathrm{D}}$ dengan perubahan diameter baling-baling

\section{5(d) Cara meningkatkan diameter baling-baling}

(i) Meminimalkan jarak bebas (clearances)

Kelonggaran tip propeller biasanya akan membatasi diameter maksimum. Jarak bebas biasanya $15 \%$

Fakultas Teknik Universitas Pattimura, ISSN : 2620-3995 sampai $20 \%$ dari diameter dan bisa sampai $25 \%$ sampai $30 \%$ diameter untuk kapal bertenaga tinggi seperti kapal kontainer besar. Untuk kapalberpenggerak tunggal, aperture buritan akan dibentuk dengan tepat untuk mengakomodasi balingbaling, namun kedekatan ujung baling-baling ke permukaan air, katakanlah dalam kondisi balas, mungkin merupakan faktor pembatas. Penggunaan skew biasanya akan menyebabkan beberapa penurunan jarak bebas, peningkatan diameter dan peningkatan efisiensi.

(ii) Terowongan buritan

Terowongan buritan telah berhasil digunakan pada kapal draft dangkal, seperti yang ditemukan di perairan pedalaman. Penggunaan terowongan memungkinkan beberapa kenaikan diameter balingbaling. Perhatian harus diberikan untuk memastikan ada pencelupan baling-baling yang memadai dan struktur tempel vertikal yang memadai dari balingbaling agar terhindar dari ventilasi baling-baling di sekitar sisi lambung kapal. Penggunaan terowongan buritan dijelaskan di Carlton [32] dan Harbaugh and Blount [33].

(iii) Inclined keel

Dalam kasus ini, keel cenderung (setara dengan perancangan trim) dan baling-baling yang jauh lebih besar dapat digunakan, [34], [35], [36]. Ini mirip dengan pendekatan yang digunakan untuk kapal tunda dan trawlers. Dalam kasus kapal yang lebih besar, seperti kapal kontainer, draft di tengah kapal akan menjadi rancangan draft dan kapal tersebut akan mengimbangi tingkat keel jika diperlukan oleh batasan draft pelabuhan. Sebagai contoh, jika kapal kargo / kontainer $145 \mathrm{~m}$ pada Tabel 1 memiliki trim buritan 2,0m, dan dengan asumsi hal ini dapat diubah (dengan perancangan ulang ujung belakang) menjadi kenaikan 1,0 $\mathrm{m}$ dalam diameter baling-baling, gunakan Gambar 5, ini akan menyarankan peningkatan efisiensi baling-baling yang diharapkan sekitar 5\%. Mungkin ada beberapa peningkatan resistansi dengan keel cenderung, namun indikasinya adalah bahwa kenaikan yang akan dihasilkan dari diameter baling-baling yang meningkat lebih besar daripada kerugian karena kenaikan resistansi. Misalnya, penelitian keelokan cenderung dilakukan oleh Seo dkk [36] menunjukkan penghematan daya keseluruhan sebesar 4\%. Keel cenderung adalah proposisi yang layak dan praktis dan temuan ini akan menyarankan agar konsep tersebut layak dipertimbangkan lebih lanjut.

(iv) Ujung baling-baling di bawah garis dasar Ini adalah plot yang digunakan di beberapa kapal perang. Diameter yang meningkat bisa diraih, namun baling-balingnya lebih mudah terkena kerusakan dan menimbulkan kesulitan saat docking. 
(v) Rudder buritan kapal

Konsep ini menggunakan apa yang secara efektif rudder digantung pada transom. Hal ini memungkinkan baling-baling digerakkan ke belakang dan diameternya meningkat secara signifikan. Tata letak seperti itu sedang diselidiki di Proyek STREAMLINE UE [37] untuk kapal tanker dan kapal RO-RO, dan perbaikan efisiensi propulsif total sebesar $15 \%$. Namun, ada beberapa keterbatasan praktis untuk tata letak semacam itu, termasuk risiko ventilasi baling-baling dan hilangnya dorongan dalam gelombang dan kerentanan kemudi dan baling-baling saat melakukan manuver dan pemasangannya.

\section{5(e) Modifikasi mendetail pada baling-baling}

Ada sejumlah modifikasi mendetail yang bisa dilakukan pada simple solid fixed-pitch propeller, termasuk penggunaan sirip tip, tip rake dan boss cap fins. Namun, dibandingkan dengan pengaruh perubahan diameter, modifikasi semacam itu pada umumnya menyebabkan perbaikan baling-baling yang relatif kecil yang sudah dirancang untuk praktik terbaik yang sudah ada.

\section{5(f) Propulsor alternatif}

Alternatif pada simple solid fixed-pitch propeller dapat dirangkum sebagai ducted, pcontrollable pitch, contra-rotating, podded units and cycloidal propellers. Umumnya, ini digunakan untuk aplikasi spesifik di mana perbaikan efisiensi pendorong dan / atau karakteristik manuver dapat dilakukan, mencatat bahwa untuk kapal dagang, unit tersebut harus tangguh, andal dan aman. Berdasarkan kebutuhan akan ketahanan dan keandalan, pendorong alternatif ini sepertinya tidak memiliki aplikasi atau dampak signifikan pada pengurangan emisi keseluruhan untuk kapal-kapal laut besar seperti kapal tanker, kapal curah dan kapal kontainer.

\subsection{INTERAKSI LAMBUNG DAN BALING- BALING}

Ini adalah area yang dapat memiliki pengaruh signifikan terhadap efisiensi propulsif secara keseluruhan. Sebagai contoh, pemeriksaan Persamaan (6) menunjukkan bagaimana thrust deduction $(t)$ dan wake fraction $\left(w_{\mathrm{T}}\right)$ mempengaruhi efisiensi lambung, sementara Persamaan (7) dan Gambar 4 mencakup kerugian rotasi $\eta_{r}$ untuk balingbaling yang mungkin dipulihkan oleh aplikasi dari perangkat yang sesuai. Interaksi baling-baling didominasi oleh kelonggaran baling-baling propeller dan bentuk lambung buritan misalnya kehalusan ujung-ujung saluran air, bergantung pada $C_{\mathrm{B}}$ dan $L C B$, dan / atau penggunaan bagian ' $U$ ' atau ' $\mathrm{V}$ ' di bagian upstream baling-baling, 12]. Hal ini dimodifikasi oleh kemungkinan adanya shaft brackets

Fakultas Teknik Universitas Pattimura, dan kemudi. Fundamental juga merupakan interaksi kemudi baling-baling, memiliki pengaruh pada thrust deduction dan beberapa pemulihan aliran rotasi baling-baling yang diinduksi, [21]. Perubahan mendasar selanjutnya adalah penggunaan 'bulbous' stern, dengan atau tanpa asimetri. Di luar aspek fundamental ini adalah perangkat terperinci yang dapat berkontribusi terhadap peningkatan efisiensi. Ini termasuk generator vortex, yang diklaim menyebabkan pengurangan konsumsi bahan bakar sebesar 4\% - 6\%, Anon [16], dan duct upstream baling-baling, yang diklaim mampu menghemat hingga $4 \%$ tenaga untuk bentuk lambungkapal yang besar, Anon [38].

Penghematan antara 2\% - 4\% dapat diharapkan dari penerapan statemen pra dan / atau post swirl. Sebuah kemudi twisted terpadu, bohlam dan baling-baling dipasang di Anon [39] dan disarankan agar penghematan daya hingga $10 \%$ dapat dicapai dengan desain lambung, baling-baling dan kemudi yang terintegrasi dengan cermat.

\subsection{MESIN PROPULSI DAN BAHAN BAKAR}

Meskipun tidak secara langsung merupakan bagian dari anggaran penghematan daya, tinjauan singkat dibuat dari mesin penggerak dan bahan bakar, dan kontribusinya untuk mengurangi emisi.

\section{7(a) Mesin propulsi}

Mesin propulsi utama bertanggung jawab untuk mengubah energi di dalam bahan bakar menjadi tenaga mekanik, Gambar 1. Jenis mesin utama, yang sesuai untuk propulsi kapal komersial dapat diringkas sebagai berikut:

- Mesin diesel kecepatan rendah, menengah dan tinggi;

- Turbin Gas;

- Motor listrik, di dalam atau di dalam drive berlapis.

- Turbin uap.

Prinsip utama dari berbagai mesin propulsi, seperti ukuran, massa, konsumsi bahan bakar dan emisi dijelaskan secara rinci di dalam Woodyard [7] dan Molland [8]. Perlu dicatat bahwa manufaktur mesin telah membuat perbaikan signifikan dalam efisiensi mesin secara keseluruhan dalam beberapa tahun terakhir, yang menyebabkan pengurangan konsumsi bahan bakar dan emisi.

\section{7(b) Bahan bakar alternatif}

Sejumlah bahan bakar alternatif sedang dipertimbangkan yang akan mengurangi emisi gas rumah kaca dan mengurangi ketergantungan pada minyak, ECSA [40]. Ini termasuk bahan bakar nabati, tenaga nuklir, LNG dan bahan bakar sel. Bahan bakar bio tidak mengandung sulfur dan mengurangi emisi $\mathrm{CO}_{2}$. Namun, harganya mahal dan mungkin tidak tersedia dalam jumlah yang sesuai untuk kegiatan 
pelayaran. Tenaga nuklir memiliki rekam jejak yang terbukti untuk kapal angkatan laut dan pemecah es. Massa dan ukuran unit nuklir telah menurun secara signifikan dan penerapan tenaga nuklir ke kapal dagang sedang ditinjau ulang, [41]. Penggunaan LNG akan mengurangi emisi $\mathrm{CO}_{2}$ dan penerapannya menjadi subyek investigasi, [42]. Volume penyimpanan yang besar yang dibutuhkan untuk LNG cenderung membuatnya kurang layak untuk kapal laut yang besar, walaupun memiliki beberapa aplikasi yang sesuai untuk kapal-kapal kecil. Bahan bakar sel bisa menjadi layak di masa depan namun, pada tingkat efisiensi energi saat ini, tidak sesuai untuk penggerak kapal besar.

\section{PENGHEMATAN DAYA SAAT OPERASI}

\subsection{KECEPATAN}

Untuk sebagian besar kapal displacement, daya pendorong bervariasi kira-kira sesuai kecepatan. Setiap pengurangan kecepatan karenanya dapat memberikan pengurangan daya yang signifikan dan emisi gas rumah kaca. Secara ekonomi, penurunan kecepatan menyebabkan penghematan bahan bakar namun hilangnya pendapatan dan ada keseimbangan yang baik antara keduanya untuk mendapatkan 'kecepatan ekonomi yang optimal'. Jika perubahan fisik diperiksa, ditemukan bahwa, pada awalnya, dimulai dari kecepatan rendah, karena kecepatan meningkat, kenaikan pendapatan meningkat pada tingkat yang lebih tinggi daripada biaya daya dan bahan bakar. Ini berlanjut sampai kecepatan tercapai ketika kenaikan biaya bahan bakar lebih besar daripada kenaikan pendapatan. Hal ini ditunjukkan secara skematis pada Gambar 6, dimana kriteria ekonomi adalah required freight rate, RFR.

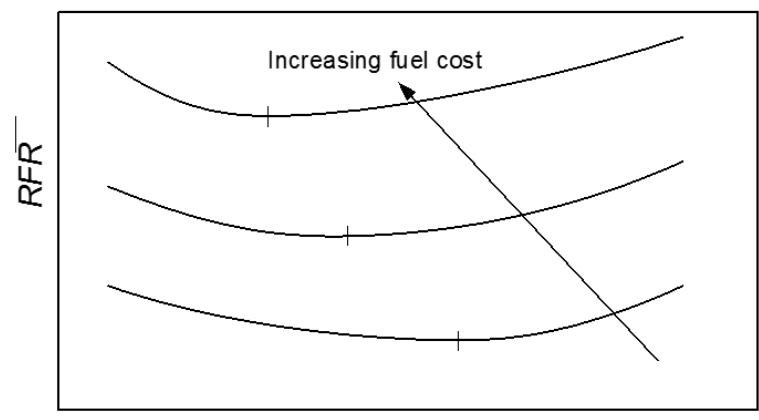

Ship speed

Gambar 6 Perubahan RFR dengan perubahan kecepatan dan biaya bahan bakar

Ditemukan bahwa kecepatan optimum menurun seiring dengan kenaikan biaya bahan bakar dan memberikan alasan untuk penggunaan kecepatan rendah, atau operational slow steaming, dalam

Fakultas Teknik Universitas Pattimura,

ISSN : 2620-3995 periode biaya bahan bakar yang tinggi. Penting untuk dicatat bahwa, untuk kapal displacement, kekuatan bervariasi (kira-kira) sebagai speed cubed, dan penurunan kecepatan akan menyebabkan penurunan indeks EEDI $\left(\mathrm{CO}_{2}\right)$, Persamaan (2), sesuai dengan kecepatan kuadrat. Misalnya, jika kecepatan kapal pada Tabel 1 dikurangi dari 16 menjadi 14 knot, maka terjadi pengurangan yang signifikan pada EEDI dari 12,89 menjadi 9,87 gm / tonne.mile. Dengan demikian cara termudah untuk mengurangi EEDI adalah dengan menurunkan kecepatan dan, untuk memenuhi batasan EEDI, metode ini diterapkan pada desain yang ada oleh sejumlah pembuat kapal dan operator. Dalam banyak kasus, keuntungan lebih lanjut dapat dilakukan dengan memasang, atau memasang perkuatan ke kapal yang ada, balingbaling yang dirancang untuk mengurangi kecepatan. Jelas bahwa pengurangan kecepatan menyebabkan pengurangan daya yang signifikan, walaupun keputusan mengenai tingkat penurunan kecepatan juga cenderung bergantung pada keseluruhan operasi sejumlah kapal untuk mengangkut sejumlah kargo tertentu.

\subsection{EFEK TRIM TERHADAP HAMBATAN LAMBUNG}

Kapal dagang biasanya dirancang untuk tingkat trim dalam load cases dan beberapa dengan trim buritan dalam kondisi balas. Ini biasanya untuk memastikan pencelupan baling-baling yang memadai dalam kasus balas bersama dengan perendaman forefoot. Efek trim terhadap ketahanan lambung telah diteliti dengan menggunakan data dari Seri BSRA [43]. Hasilnya adalah untuk kapal standar BSRA dengan L $=122 \mathrm{~m}$ dan $\mathrm{B}=16.8 \mathrm{~m}$. Kondisi ballast diuji pada draft setara dengan $4.9 \mathrm{~m}$ pada tingkat keel dan dengan trim buritan sebesar 2,4m. Hasil pada rentang kecepatan untuk tiga koefisien blok ditunjukkan pada Gambar 7. Hal ini terlihat dari Gambar 7 bahwa perubahan signifikan pada ketahanan lambung dapat terjadi dengan perubahan pada trim.Dalam kasus kapal $\mathrm{CB}=0,65$, perubahan utama terjadi pada kecepatan yang lebih tinggi, di mana penurunan resistansi hingga 3,5\% diamati. Kasus $\mathrm{CB}=0,70$ menunjukkan penurunan ketahanan hingga $5 \%$ pada kecepatan yang lebih tinggi. Untuk $\mathrm{CB}=0,75$, ketahanan dalam kondisi terpangkas adalah sampai 6\% lebih tinggi pada kecepatan rendah dan sampai $3 \%$ lebih rendah pada kecepatan yang lebih tinggi. Hasil pada Gambar 7 berfungsi untuk menggambarkan tingkat perubahan hambatan lambung dengan perubahan trim. Pada saat bersamaan, perubahan trim dapat mengubah faktor efisiensi lambung seperti wake fraction, dengan konsekuensi perubahan efisiensi pendorong secara keseluruhan. 
Investigasi keseluruhan harus mempertimbangkan dampak tersebut. Larsen dkk [44] memberikan penjelasan bagus tentang sumber perubahan daya karena perubahan pada trim. Penyelidikan mereka menemukan bahwa sebagian besar daya pendorong yang berubah berasal dari koefisien hambatan sisa. Efek trim terhadap hambatan lambung kapal tertentu dapat ditentukan pada tahap pengujian uji tarik model, dan / atau dengan penggunaan CFD, yang dapat memberikan panduan kepada operator kapal. Sebagai alternatif, penyelidikan dapat dilakukan di kapal dalam pelayanan dengan memantau konsumsi daya atau bahan bakar (F) selama periode waktu tertentu untuk jumlah trim yang berbeda. Dengan cara yang mirip dengan analisis pelayaran [31], perubahan karena trim dapat dipantau dengan menggunakan faktor $F_{\mathrm{C}}$, seperti yang dijelaskan pada Persamaan (12), yang juga dapat memperbaiki perubahan displacement $(\Delta)$ dan kecepatan $(\mathrm{V})$.

$$
F_{C}=\frac{\Delta^{2 / 3} V^{3}}{F}
$$

Hansen dan Freund [45] menjelaskan sebuah penelitian terperinci mengenai derivasi efek trim dan penerapan pada kapal yang beroperasi. Sekarang ada sejumlah paket perangkat lunak komersial yang tersedia untuk operator kapal yang dapat menghitung alternatif trim dan ballasting yang optimum. Diklaim bahwa paket tersebut dapat menyebabkan penghematan keseluruhan hingga 5\%.

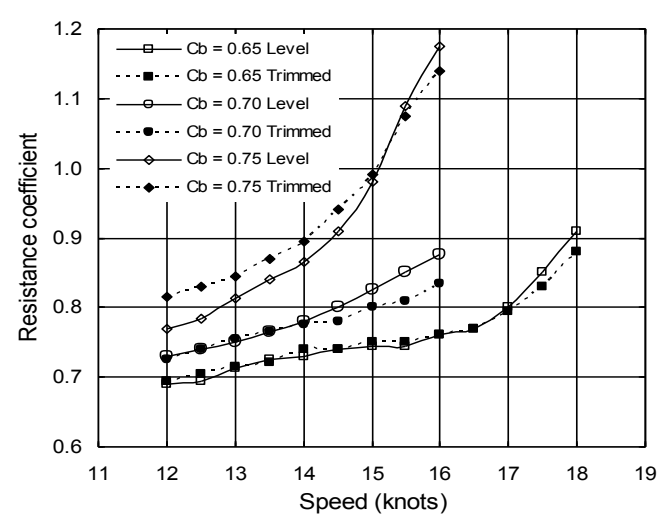

Gambar 7:Efek trim pada hambatan lambung

\subsection{RUTE CUACA}

Saat inisebuah prosedur yang dipraktikkan dengan baik oleh banyak perusahaan pelayaran. Ada banyak paket perangkat lunak komersial yang tersedia dan layanan rute yang memudahkan prosedur. Ini menyebabkan penurunan relatif konsumsi bahan bakar untuk peningkatan jarak saat melakukan perjalanan di sekitar cuaca buruk. Untuk bekerja secara efektif, pengetahuan dibutuhkan dari kinerja kapal di seaway, khususnya, penurunan kecepatan

Fakultas Teknik Universitas Pattimura,

ISSN : 2620-3995

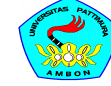

dalam berbagai kondisi laut yang diperkirakan. Prosedur seperti itu, misalnya, dijelaskan oleh Satchwell [46]. Praktik tersebut harus mengarah pada keseluruhan penghematan daya dan emisi gas rumah kaca yang kurang.

\subsection{PEMBERSIHAN LAMBUNG/PROPELLER}

Pembersihan lambung diketahui dapat mengurangi keseluruhan daya, namun biasanya dilakukan dengan dasar ekonomi yang ketat, lihat Townsin dkk [18], [19], [20]. Tingkat indikatif perubahan efisiensi dengan kekasaran diberikan pada Bagian 4.2 dan 4.5 (b). Penurunan emisi $\mathrm{CO}_{2}$, dan kemungkinan perdagangan emisi untuk kenaikan biaya perawatan, dapat memberi operator insentif untuk membersihkan lambung dan baling-baling selama interval waktu yang lebih pendek. Juga dapat dicatat bahwa aplikasi cat baling-baling telah berkembang selama beberapa tahun terakhir, dengan meningkatnya penggunaan cat antifouling, terutama pada baling-baling kapal kargo besar, [17], [47].

\section{PERANGKAT PROPULSI TAMBAHAN}

Ada sejumlah perangkat yang memberikan daya dorong menggunakan energi terbarukan. Sumber energi adalah angin, gelombang dan matahari. Perangkat yang menggunakan sumber ini dijelaskan dalam referensi seperti [48], [49], [50], [51], [52] dan [53].

Sementara sejumlah perangkat mungkin tidak praktis menyangkut propulsi, beberapa, seperti turbin angin dan panel surya, dapat digunakan untuk memberi tenaga tambahan kepada generator tambahan. Hal ini akan menyebabkan penurunan daya keseluruhan (propulsi dan pembangkit listrik tambahan) dan pengurangan keseluruhan gas rumah kaca yang dipancarkan.

\section{ISU EKONOMI DAN LINGKUNGAN}

Faktor-faktor yang mendorong penelitian dan penyelidikan saat ini untuk meningkatkan efisiensi propulsi kapal secara keseluruhan adalah ekonomi dan lingkungan. Pada dasarnya, perbaikan efisiensi propulsi harus mengarah langsung pada perbaikan pada pengembalian ekonomi dan penurunan emisi gas rumah kaca. Artinya ada insentif ganda untuk mengejar peningkatan efisiensi tersebut. Namun ada beberapa kemungkinan perubahan teknis yang akan menurunkan emisi, namun hal itu mungkin tidak layak secara ekonomi. Misalnya, penggunaan controllable pitch propellers atau contra-rotating propellers untuk meningkatkan efisiensi dan menurunkan emisi, keduanya cenderung menimbulkan kenaikan biaya perawatan dan biaya pertama, yang mengurangi efisiensi ekonomi. Banyak

. 2620-3995 
mesin bantu, yang menggunakan sumber energi terbarukan, dan cat lambung yang disempurnakan, cenderung masuk ke kategori ini. Ada saran bahwa perdagangan emisi untuk kapal atau, pada dasarnya, beberapa bentuk 'subsidi' untuk mengurangi emisi, dapat diperkenalkan di masa depan. Jika demikian, semua sarana perbaikan dalam penguasaan dan pengurangan emisi gas rumah kaca harus dieksplorasi dan dinilai, bahkan jika perbaikan semacam itu mungkin tidak berjalan secara ekonomis secara ekonomi.

Studi telah dilakukan selama bertahun-tahun untuk mendapatkan kombinasi parameter lambung yang paling sesuai untuk kapal tertentu pada kecepatan tertentu dengan biaya bahan bakar tertentu. Analisis biasanya didasarkan pada beberapa ukuran ekonomi jasa, seperti NPV, yield atau tingkat pengangkutan yang diperlukan, RFR. Dimensi yang dihasilkan akan tergantung pada kecepatan, biaya pembangunan dan biaya bahan bakar. Misalnya, jika kecepatan berkurang, kapal akan cenderung lebih pendek dan biaya konstruksi akan berkurang, sementara untuk biaya bahan bakar yang lebih tinggi, panjang optimal dan L / B cenderung lebih besar, penurunan daya dan bahan bakar mengimbangi kenaikan biaya pembangunan. Contoh dari penyelidikan semacam itu diberikan di [54] di mana perubahan parametrik dalam dimensi lambung utama untuk kapal tanker dilakukan oleh perusahaan minyak terkemuka, memberikan indikasi tentang penghematan daya yang mungkin dicapai.

Sebuah studi telah dibuat menjadi efek perubahan parametrik pada parameter lambung kapal kargo / kontainer kecil yang dijelaskan pada Tabel 1. Hal ini mengharuskan kapal mencapai 16 knot dengan 18 pelayaran / tahun dan mengubah rasio L / B secara metodis. Perangkat lunak perancangan Kapal ShipDes, dijelaskan oleh Molland dkk. [52], digunakan untuk penyelidikan. ShipDes terutama adalah program desain teknis yang mengevaluasi dimensi utama kapal untuk memberi nilai masukan bobot, kecepatan dan jangkauan mati. Ini juga melakukan analisis ekonomi yang disederhanakan untuk mengevaluasi tingkat pengangkutan yang diperlukan, RFR. Ini memerlukan perkiraan biaya operasi, termasuk perawatan, kru dan bahan bakar, dan biaya modal dengan menggunakan perkiraan biaya konstruksi dan faktor pemulihan modal, CRF. Hasilnya ditunjukkan pada Gambar 8. Perubahan biaya konstruksi / biaya tahunan dan perubahan biaya bahan bakar mengikuti tren yang diharapkan, yaitu, kenaikan L / B, biaya konstruksi dan kenaikan biaya tahunan dan biaya bahan bakar menurun. Pengamatan hasil RFR pada Gambar 8 menunjukkan bahwa dengan bahan bakar sebesar \$300/ ton, L / B seharusnya sekitar 6,7. Gambar 8 juga menggambarkan bagaimana daya L / B dan penurunan yang lebih tinggi menghasilkan indeks Fakultas Teknik Universitas Pattimura, ISSN : 2620-3995
$\mathrm{CO} 2$ yang lebih rendah (EEDI). Namun, di atas L / B sekitar 6,7, RFR cenderung meningkat, yang menyebabkan penurunan efisiensi ekonomi. Ini menggambarkan tuntutan efisiensi lingkungan dan efisiensi ekonomi yang saling bertentangan. Yang penting diperhatikan adalah bahwa, dengan harga bahan bakar yang tinggi, dan tekanan untuk mengurangi emisi dan tenaga, mungkin perlu pindah ke tempat yang lebih tinggi.

Rasio L / B dari pada saat ini adalah praktik. Dengan basis yang sama, nilai yang sesuai untuk parameter lambung lainnya, seperti B / T, CB dan LCB, juga harus dikunjungi kembali.Jelas bahwa pengaruh gabungan dari biaya bahan bakar dan emisi CO2 cenderung mengambil peran yang lebih penting dalam pemilihan parameter lambung keseluruhan untuk tonase di masa depan.
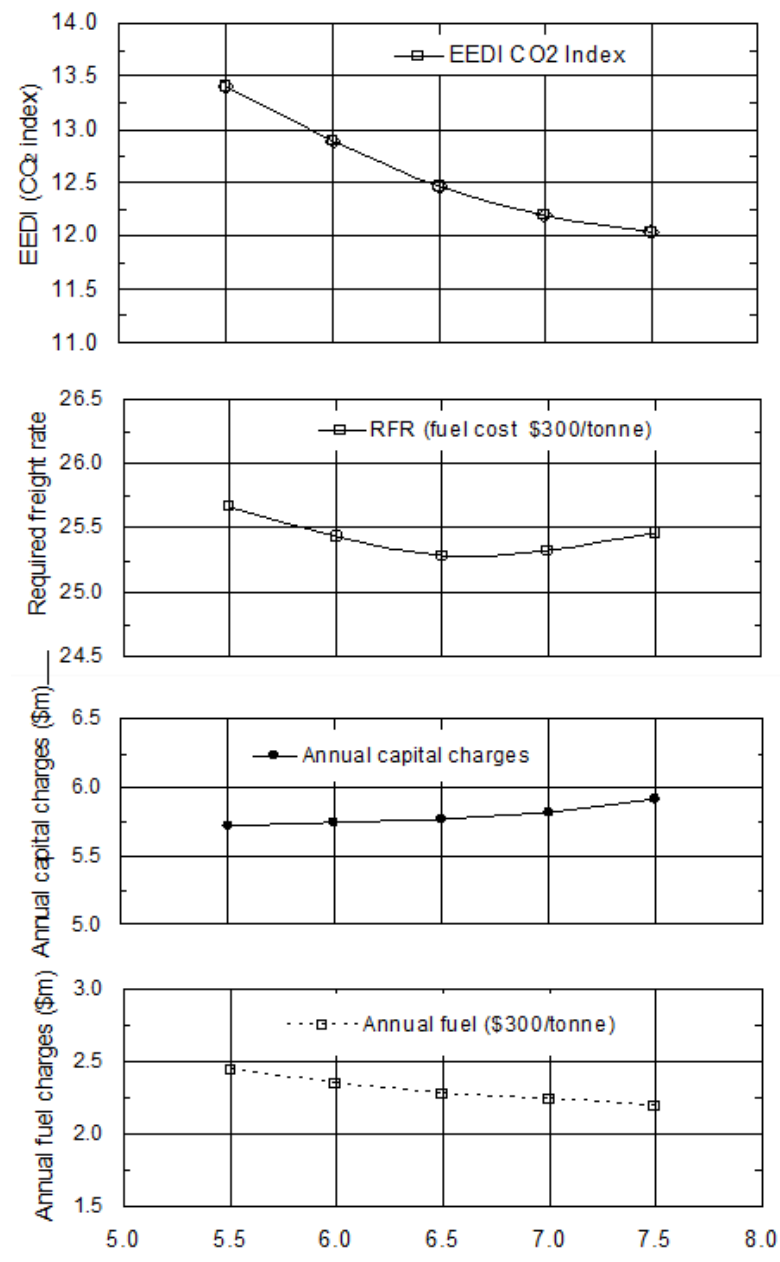

Gambar 8: Pengaruh L / B terhadap biaya tahunan dan bahan bakar, Diperlukan Freight Rate dan indeks $\mathrm{CO} 2$ (EEDI) 


\section{PROSEDUR DESAIN}

Jelas dari Bagian sebelumnya bahwa prosedur untuk mengukur dampak emisi gas rumah kaca perlu digabungkan dalam proses perancangan kapal. Ini bisa, misalnya, memerlukan penggabungan EEDI (Persamaan (2)) sebagai fungsi objektif. Gambar 9 menunjukkan pendekatan desain kapal tradisional dimana fungsi objektif, atau ukuran kelayakannya, adalah beberapa kriteria ekonomi seperti NPV atau RFR, Molland [8], Schneekluth dan Bertram [55], Watson [56].

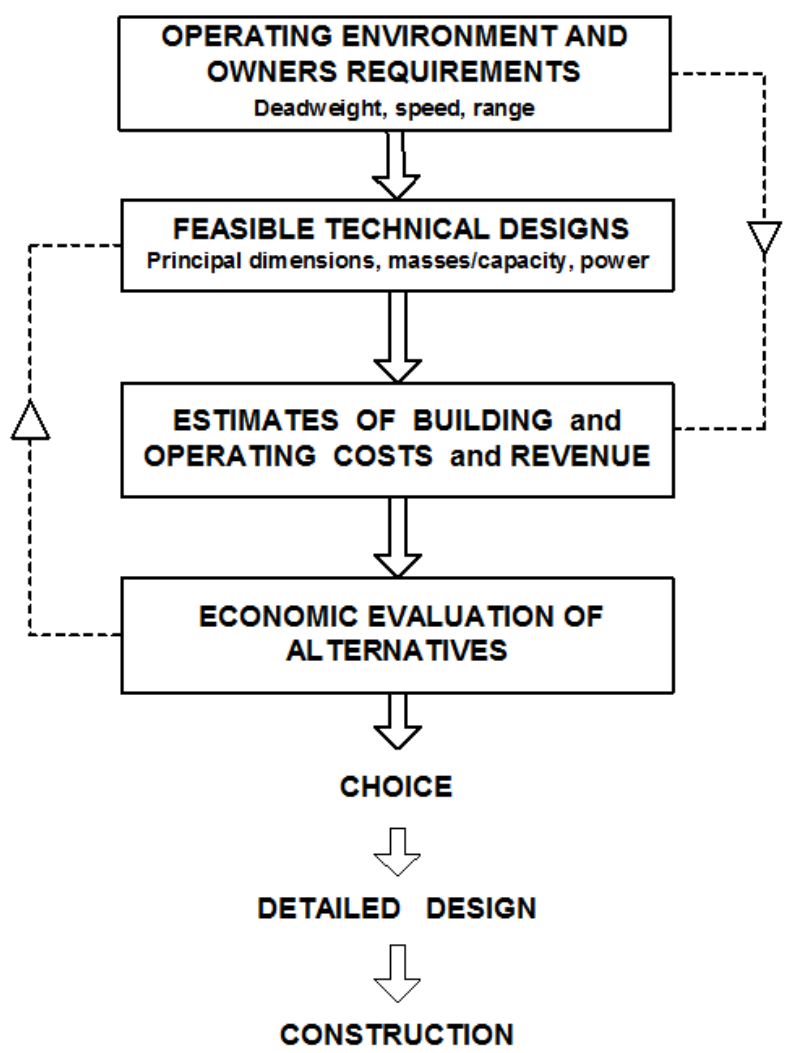

Gambar 9: Keseluruhan alur proses desain

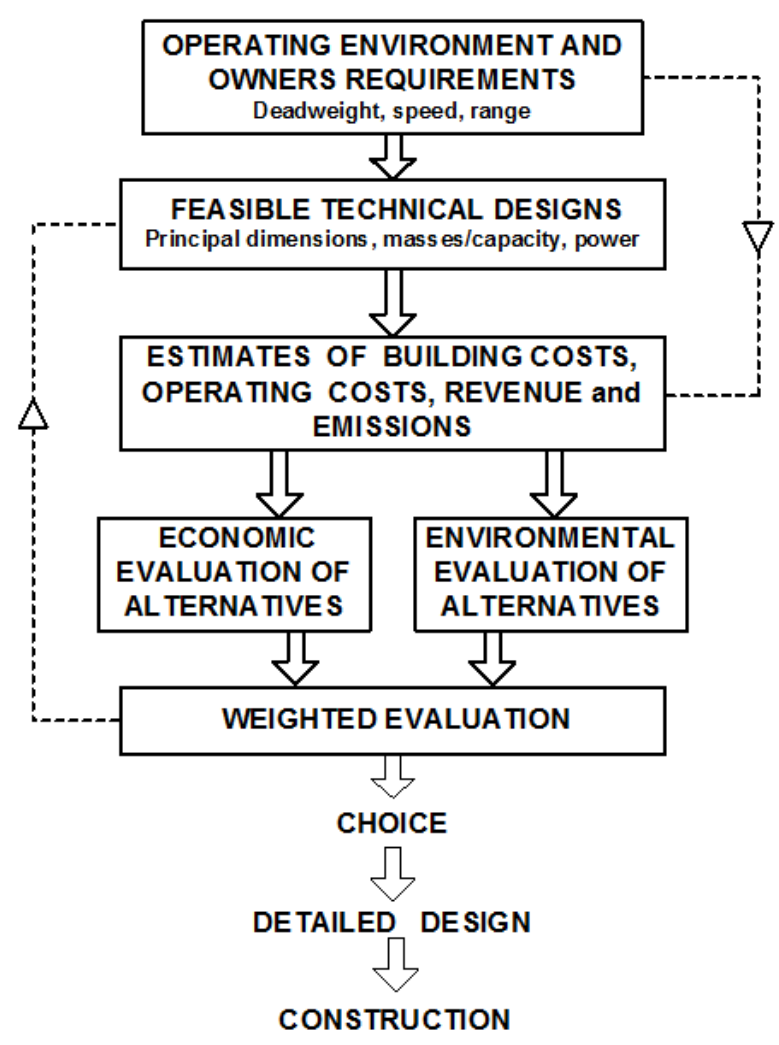

Gambar 10: Keseluruhan alur proses desain dengan menggabungkan efek lingkungan

Gambar 10 menunjukkan bagaimana efek lingkungan dapat digabungkan dalam proses perancangan kapal. Penggunaan pendekatan semacam itu memungkinkan perubahan desain, inovasi teknis dan perangkat kekuatan tambahan untuk digabungkan dalam desain teknis yang layak, dan analisis biaya manfaat dari perubahan ini dilakukan dengan cara biasa, Schneekluth dan Bertram [55]. Dengan demikian, fungsi objektif untuk mengoptimalkan basis ekonomi mungkin adalah NPV atau RFR, sementara 'optimal' lingkungan mungkin mencapai EEDI terendah. Contoh sebelumnya, seperti yang diilustrasikan pada Gambar 8, telah mengindikasikan bahwa optima ekonomi dan lingkungan mungkin tidak bersamaan.

Jalur desain sekarang menjadi beberapa masalah kriteria, lihat misalnya Sen [57] dan Schneekluth dan Bertram [55]. Bobot harus diterapkan tergantung pada insentif keuangan apa yang diberikan, secara langsung atau tidak langsung, sampai pada optimum lingkungan yang belum tentu optimal secara ekonomi. Pembobotan cenderung bergantung pada tingkat biaya bahan bakar, perubahan untuk mencapai EEDI dan insentif yang diperlukan dalam skema perdagangan karbon. 


\section{KESIMPULAN}

9.1 Umum: Sejumlah area telah diidentifikasi dimana perubahan desain awal dan investasi pada tahap konstruksi dapat menyebabkan penghematan daya pendorong, konsumsi bahan bakar dan emisi gas rumah kaca. Perubahan dapat dilakukan pada tahap desain / pembangunan, atau modifikasi yang dilakukan saat kapal sedang dalam pelayanan. Apapun perubahan yang dilakukan dan perangkat hemat energi yang diajukan, ini harus praktis, tangguh, andal dan aman.

9.2 Resistensi: Beberapa area telah diidentifikasi dimana kinerja propulsif secara keseluruhan dapat ditingkatkan. Dalam hal ketahanan, optimalisasi parameter bentuk lambung secara keseluruhan dapat diselidiki, bersama dengan memperhatikan ujung depan pada bulbous bows dan bentuk bagian lokal, dan pada bagian belakang dalam hal bentuk bagian dan interaksi wake dengan baling-baling. CFD digunakan dengan baik untuk mengembangkan bentuk lambung yang sesuai untuk kondisi operasional tertentu. Namun, temuan tersebut menunjukkan bahwa penurunan ketahanan lambung keseluruhan dapat dicapai secara relatif kecil jika dibandingkan dengan praktik yang ada.

9.3 Efisiensi propeller: Perbaikan kecil lokal dapat dilakukan pada baling-baling yang sudah dirancang untuk praktik terbaik yang ada, namun efisiensi keseluruhan didominasi oleh diameter, dengan keuntungan hingga 5\% dimungkinkan saat pergi dari diameter kecil sampai diameter maksimum. Cara memaksimalkan diameter telah diidentifikasi termasuk penggunaan keel cenderung.

9.4 Interaksi Lambung-propeller-kemudi: Perhatian terhadap interaksi lambung-baling-kemudi menawarkan ruang lingkup untuk pengurangan daya yang signifikan. Pengurangan 5\% - 10\% dapat diklaim. Teknik meliputi mengadaptasi lambung ke belakang dengan menggunakan sterns asimetris dan bulbous sterns, pengkondisian aliran ke upstream baling-baling menggunakan perangkat pre-swirl dan pemulihan energi rotasi downstream baling-baling menggunakan kemudi twisted dan perangkat postswirl. CFD digunakan dengan tepat untuk melengkapi tes model untuk efek interaksi lambungbaling-rudal semacam itu.

9.5 Operasi: Ditemukan bahwa penghematan daya yang paling menguntungkan berasal dari strategi operasional yang optimal, seperti penggunaan trim, speed dan rute cuaca yang optimal. Operator telah melaporkan penghematan keseluruhan hingga 5\% dengan menerapkan teknik tersebut.

Fakultas Teknik Universitas Pattimura, ISSN : 2620-3995

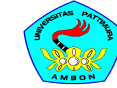

9.6 Penghematan: Dalam bereaksi terhadap tekanan untuk mengurangi daya propulsi, perancang perlu menyelidiki setiap kemungkinan yang mungkin terjadi. Hal ini mungkin memerlukan perbaikan kecil dari sejumlah komponen yang secara kolektif harus memberikan penghematan yang berharga dalam keseluruhan daya dan pengurangan emisi gas rumah kaca..

9.7 Kelangsungan ekonomi: Dengan meningkatnya tekanan dari sudut pandang lingkungan dan dengan kemungkinan penerapan skema perdagangan emisi di masa mendatang, pengurangan daya dan emisi dapat dicapai dengan perubahan desain dan investasi pada perangkat hemat bahan bakar yang belum tentu merupakan solusi ekonomi terbaik. Tuntutan yang bertentangan dapat terjadi saat mencoba mencapai efisiensi ekonomi dan lingkungan.

9.8 Prosedur perancangan: Proses perancangan harus disesuaikan untuk memperhitungkan penekanan perubahan antara viabilitas ekonomi dan faktor lingkungan, seperti emisi gas rumah kaca. Prosesnya akan mencakup beberapa fungsi tujuan ekonomi, seperti NPV atau RFR, dan fungsi tujuan lingkungan yang bisa menjadi EEDI. Pendekatan beberapa kriteria akan diperlukan, dengan pembobotan antara kriteria tergantung pada tingkat biaya bahan bakar dan pada insentif keuangan apa yang mungkin timbul untuk meyakinkan operator kapal untuk mengurangi emisi.

\section{REFERENSI}

1. IMO. Guidelines on the Method of Calculation of the Attained Energy Efficiency Design Index (EEDI) for new ships. Resolution of the Marine Protection Environment Committee, MEPC.212(63), 2012.

2.IMO. Guidelines on Survey and Certification of the Energy Efficiency Design Index (EEDI). Resolution of the Marine Protection Environment Committee, MEPC.214(63), 2012.

3. TURNOCK, S.R. Minimising the environmental impact of shipping: clean ships for a new century. Proceedings of Marienv'95. Society of Naval Architects of Japan, 1995.

4. JAMES, M.C., TURNOCK, S.R. and HUDSON, D.A. Design of retrofit devices using CFD, validated with wind tunnel tests. NUTTS, 2012: 15th Numerical Towing Tank Symposium, Cortona, Italy, 2012.

5. MARPOL, Convention of IMO, Annex VI, 2008.

6. MCA, Maritime and Coastguard Agency, Merchant Shipping Notice 1819 (M + F), 2008.

7. WOODYARD, D.F. Pounder's Marine Diesel Engines and Gas Turbines. 8th Edition. Butterworth-Heinemann, Oxford, UK, 2004. 
8. MOLLAND, A.F. (ed) The Maritime Engineering Reference Book. ButterworthHeinemann, Oxford, UK, 2008.

9. MOLLAND, A.F.,WELLICOME, J.F. and COUSER, P.R.Resistance experiments on a systematic series of high speed displacement catamaran forms: Variation of lengthdisplacement ratio and breadth-draught ratio. Transactions of the Royal Institution of Naval Architects, Vol. 138, 1996.

10. MOLLAND, A.F., WILSON, P.A., TAUNTON, D.J., CHANDRAPRABHA, S. and GHANI, P.A. Resistance and wash Measurements on a Series of High Speed Displacement Monohull and Catamaran Forms in Shallow Water. Transactions of the Royal Institution of Naval Architects, Vol. 146, 2004.

11. HOCHKIRCH, K. and BERTRAM, V. Hull optimisation for fuel efficiency - past, present future. Eleventh International Conference on Computer and IT Applications in the Maritime Industries, COMPIT'12, Liege, Belgium, 2012.

12. PLOEG, A van der. Object functions for optimising a ship's aft body. Eleventh International Conference on Computer and IT Applications in the Maritime Industries, COMPIT'12, Liege, Belgium, 2012.

13. BSRA Methodical Series Experiments on SingleScrew Ocean-Going Merchant Ship Forms. Extended and Revised Overall Analysis. BSRA Report NS333, 1971.

14. KRACHT, A.M. Design of bulbous bows. Transactions of the Society of Naval Architects and Marine Engineers, Vol. 86, 1978.

15. HOCHKIRCH, K. and BERTRAM, V. Slow steaming bulbous bow optimisation for a large container ship. Eighth International Conference on Computer and IT Applications in the Maritime Industries, COMPIT'09, Budapest, 2009.

16. ANON The SHI SAVER Fin. Marine Power and Propulsion Supplement, The Naval Architect, RINA, London, 2008.

17. CANDRIES, M. and ATLAR, M. On the drag and roughness characteristics of antifoulings. Transactions of the Royal Institution of Naval Architects, Vol.145, 2003.

18. TOWNSIN, R.L., BYRNE, D., MILNE, A. and SVENSEN, T. E. Speed, power and roughness: The economics of outer bottom maintenance. Transactions of the Royal Institution of Naval Architects, Vol.122, 1980.

19. TOWNSIN, R.L., BYRNE, D., SVENSEN, T. E. and MILNE, A. Estimating the technical and economic penalties of hull and propeller roughness. Transactions of the Society of Naval Architects and Marine Engineers, 1981.
20. TOWNSIN, R.L., BYRNE, D., SVENSEN, T. E. and MILNE, A. Fuel economy due to improvements in ship hull roughness 19761986. International Shipbuilding Progress, Vol.33, 1986.

21. MOLLAND, A.F and TURNOCK, S.R. Marine Rudders and Control Surfaces. ButterworthHeinemann, Oxford, UK. 2007.

22. ITTC Report of Resistance Committee, 26th International Towing Tank Conference, Rio de Janeiro, 2011.

23. ISHERWOOD, R.M. Wind Resistance of Merchant Ships. Transactions of the RoyalInstitution of Naval Architects, Vol. 115, 1973.

24. BERLEKOM, Van W.B. Wind Forces on Modern Ship Forms - Effects on Performance. Transactions of the North East Institute of Engineers andShipbuilders, Vol. 97, No. 4, 1981.

25. GOULD, R.W.F. The Estimation of Wind Loadings on Ship Superstructures. R.I.N.A. Marine Technology Monograph No. 8, 1982.

26. MOLLAND, A.F. and BARBEAU, T-E.An Investigation into the Aerodynamic Drag on the Superstructures of Fast Catamarans. Transactions of the Royal Institution of Naval Architects, Vol.145, 2003.

27. HOERNER, S.F. Fluid-Dynamic Drag. publ. by the Author. Washington, USA, 1965

28. HUCHO, W-H. (Editor) Aerodynamics of Road Vehicles. 4th Edition. Society ofAutomotive Engineers, Inc., USA, 1998.

29. DYNE, G. The efficiency of a propeller in uniform flow. Transactions of the RoyalInstitution of Naval Architects, Vol.136, 1994.

30. DYNE, G. The principles of propulsion optimisation. Transactions of the RoyalInstitution of Naval Architects, Vol.137, 1995

31. MOLLAND, A.F., TURNOCK, S.R. and HUDSON, D.A. Ship Resistance and Propulsion. Cambridge University Press, Cambridge, UK, 2011.

32. CARLTON, J.S. Marine Propellers and Propulsion. Third Edition. ButterworthHeinemann, Oxford, UK, 2012.

33. HARBAUGH, K.H. and BLOUNT, D.L. An experimental study of a high performance tunnel craft. Paper H, Society of Naval Architects and Marine Engineers, Spring Meeting, 1973.

34. WINTERS, R.D.E. Application of a large propeller to a container ship with keel drag. Transactions of the Royal Institution of Naval Architects, Vol.140, 1998. 
35. SEO, K-C., ATLAR, M. and SAMPSON, R. Hydrodynamic development of inclined keel Resistance. Ocean Engineering, No. 47, 2012, pp 7-18.

36. SEO, K-C., ATLAR, M. and Wang, D. Hydrodynamic development of inclined keel hull - Propulsion. Ocean Engineering. Vol.63, 2013. pp 7-18.

37. ANON. Streamlining project makes efficiency gains. The Naval Architect, RINA, London, January, 2013.

38. ANON (2008a) The Mewis Duct. Marine Power and Propulsion Supplement, The Naval Architect, RINA, London, 2008.

39. ANON (2008b) The integrated propulsion manoeuvring system. Ship and Boat International, RINA, London, September/October 2008.

40. ECSA. Climatic change and shipping: ECSA position paper. European Community Shipowners' Associations (ECSA), January, 2008.

41. CARLTON, J., SMART, B. and JENKINS, V. The nuclear propulsion of merchant ships: aspect of engineering, science and technology. Journal of Marine Engineering and Technology, 2011.

42. LLOYD'S REGISTER. LNG as fuel. Shipping and the Environment, Issue 03, 2012.

43. LACKENBY, H. and PARKER, M.N. The BSRA Methodical Series - An overall Presentation: Variation of resistance with breadth-draught ratio and length-displacement ratio. Transactions of the Royal Institution of Naval Architects, Vol. 108, 1966.

44. LARSEN, N.L., SIMONSEN, C.L., NEILSEN, C.K. and HOLM, C.R. Understanding the physics of trim. Ninth Annual Green Ship Technology Conference, Copenhagen, March 2012.

45. HANSEN, H. and FREUND, M. Assistance tools for operational efficiency. Ninth International Conference on Computer and IT
Applications in the Maritime Industries, COMPIT'10, Gubbio, 2010.

46. SATCHWELL, C. J. Windship technology and its application to motor ships. Transactions of the Royal Institution of Naval Architects, Vol.131, 1989.

47. ITTC Report of Specialist Committee on Surface Treatment. 26th International Towing Tank Conference, Rio de Janeiro, 2011.

48. RINA 1980 Proceedings of the Symposium on Wind Propulsion of Commercial Ships. The Royal Institution of Naval Architects, London, 1980.

49. WINDTECH'85 International Symposium on Windship Technology. University of Southampton, UK, 1985.

50. ANON. Christening and launch of 'E-Ship1' in Kiel. The Naval Architect, RINA, London, September, 2008.

51. ANON. Skysails hails latest data. The Naval Architect, RINA, London, September, 2008.

52. NYK. Eco Ship: Operation tests getting under way. NYK News Release, August 2004.

53. MOLLAND, A.F., TURNOCK, S.R. and HUDSON, D.A. Design metrics for evaluating the propulsive efficiency of future ships. InternationalMarine Design Conference, IMDC'09, Trondheim, 2009.

54. SSPA HIGHLIGHTS. Newsletter published by SSPA, 3/2007.

55. SCHNEEKLUTH, H. and BERTRAM, V. Ship Design for Efficiency and Economy. 2nd edition, Butterworth-Heinemann, Oxford, UK. 1998.

56. WATSON, D.G.M. Practical Ship Design. Elsevier Science Ltd., Oxford, UK, 1998.

57. SEN, P. Marine design: The multiple criteria approach. Transactions of the Royal Institution of Naval Architects, Vol.134, 1992. 